\title{
Understanding antibiotic resistance via outer membrane permeability
}

This article was published in the following Dove Press journal: Infection and Drug Resistance

\author{
Ishan Ghai ${ }^{1,2}$ \\ Shashank Ghai ${ }^{3}$ \\ 'School of Engineering and Life \\ Sciences, Jacobs University, Bremen, \\ Germany; ${ }^{2}$ Consultation Division, \\ RSGBIOGEN, New Delhi, India; \\ ${ }^{3}$ Leibniz University Hannover, \\ Hannover, Germany
}

Correspondence: Shashank Ghai Leibniz University, Welfengarten I, 30167 Hannover, Germany Email ishanghai@live.com

\begin{abstract}
Collective antibiotic drug resistance is a global threat, especially with respect to Gram-negative bacteria. The low permeability of the bacterial outer cell wall has been identified as a challenging barrier that prevents a sufficient antibiotic effect to be attained at low doses of the antibiotic. The Gram-negative bacterial cell envelope comprises an outer membrane that delimits the periplasm from the exterior milieu. The crucial mechanisms of antibiotic entry via outer membrane includes general diffusion porins (Omps) responsible for hydrophilic antibiotics and lipid-mediated pathway for hydrophobic antibiotics. The protein and lipid arrangements of the outer membrane have had a strong impact on the understanding of bacteria and their resistance to many types of antibiotics. Thus, one of the current challenges is effective interpretation at the molecular basis of the outer membrane permeability. This review attempts to develop a state of knowledge pertinent to Omps and their effective role in solute influx. Moreover, it aims toward further understanding and exploration of prospects to improve our knowledge of physicochemical limitations that direct the translocation of antibiotics via bacterial outer membrane.

Keywords: antibiotics, Gram-negative bacteria, drug-resistance, outer membrane proteins, porins, membrane permeability, influx
\end{abstract}

\section{Introduction}

At the end of the 20th century, the attention of the scientific as well as the pharmaceutical community regarding the threat of antibiotic resistance was mainly focused on multiresistant Gram-positive bacteria. ${ }^{1,2}$ This significantly contributed towards the development of new compounds with the specific activity against this particular group of microorganisms. ${ }^{1}$ Regrettably, the introduction of antibiotics for Gram-negative bacteria has not developed at a similar pace. ${ }^{1}$ Gram-negative bacterial multidrug resistance is a worrying health issue. Antibiotic resistance is frequently reported in clinical Gram-negative bacteria, and severely limits the available therapeutic options in hospital acquired infections., ${ }^{2,3}$ Consequently, due to the shortage of novel active antibacterials, there is an immense need to interpret the molecular mechanisms of antibiotic resistance, especially toward key Gram-negative clinical pathogens, such as Klebsiella, Enterobacter, Pseudomonas, Campylobacter, Acinetobacter, and Salmonella species. ${ }^{4-8}$

The current innovative mode of improving the potential of antibiotics is to efficiently introduce them into the bacteria and further prevent them from degradation by bacterial enzymes before they reach their targets. ${ }^{7,8}$ This is, however, an extreme method for countering the problem of antibiotic resistance. ${ }^{9,10}$ The main mechanisms employed by Gram-negative bacteria against available antibiotic therapy include the enzymatic barrier, which primarily destroys the antibiotics; the membrane barrier, 
which limits the intracellular access of antibiotics; and antibiotic target modification, resulting in the overall failure of antibiotic therapy. ${ }^{7}$ Significantly, these mechanisms can work together in clinical isolates, thus creating an elevated level of antibiotic resistance. ${ }^{4,6,8}$ Of these mechanisms, antibiotic infusion across the bacterial membranes ${ }^{11}$ is one of the crucial mechanisms that needs to be studied thoroughly. ${ }^{5-9}$ Passing over toward the outer membrane barricade to scope the inhibitory concentration inside the bacterial cell is a key step for antibiotic molecules to work effectively, ${ }^{11}$ thus, understanding the mechanism of transport across the outer membrane will give a crucial insight towards designing futuristic "smart" antibiotics. ${ }^{7,8,10}$ The outer membrane of Gram-negative bacteria performs the crucial role of providing an extra layer of protection to the organism without conceding the exchange of material required for sustaining life. In this dual capacity, this barrier appears to be an extremely sophisticated macromolecular assemblage, the complexity of which has been explored only in recent years..$^{5,8,12-15}$ By combining a highly hydrophobic lipid bilayer containing pore-forming proteins (Omps) (Tables 1 and 2) of specific size-exclusion properties, the outer membrane acts as a selective barricade. ${ }^{7,8}$ The permeability properties of this barrier, therefore, have a major impact on the susceptibility of the microorganism to antibiotics. Small hydrophilic drugs, such as $\beta$-lactams, use the pore-forming porins to gain access to the cell interior, while macrolides and other hydrophobic drugs diffuse across the lipid bilayer. ${ }^{4,12,13}$ The existence of drug-resistant strains in many bacterial species due to modifications in the lipid or protein composition of the outer membrane indeed highlights the importance of the outer membrane barrier in antibiotic sensitivity. For instance, any structural changes in the available outer membrane proteins can significantly account for antibiotic resistance. ${ }^{5}$ Further, the situation becomes serious when the permeability barrier synchronizes with the $\beta$-lactamases in the periplasmic space, potentially leading to third-generation cephalosporin resistance. ${ }^{4-7}$ In Gram-negative bacteria, the outer membrane is an asymmetric bilayer of phospholipid and lipopolysaccharides (LPS), with the latter exclusively found in the outer leaflet. ${ }^{4,5} \mathrm{~A}$ typical LPS molecule consists of three parts, together with a relatively short core oligosaccharide, lipid A, a glucosaminebased phospholipid, and a distal polysaccharide O-antigen. ${ }^{12}$ Since part of the core oligosaccharide and the O-antigen are not required for the growth of Escherichia coli, strains can exhibit varying lengths of these structures. ${ }^{4,5,12,13}$ The phospholipid composition of the inner leaflet of the outer membrane contains approximately $15 \%$ phosphatidylglycerol, $80 \%$ phosphatidylethanolamine, and 5\% cardiolipin, like that of the cytoplasmic membrane. ${ }^{12}$ Many different types of proteins reside in the outer membrane (Table 1). Some of them are extremely abundant. Different outer membrane proteins have been characterized in Gram-negative bacteria (Table 2) and are distinguished according to their substrate specificities, functional structure (monomeric or trimeric), and their regulation and expression. ${ }^{4-6,12,13}$

In this present review, we discuss and tabulate different attributes to understand various outer membrane proteins mainly responsible for solute influx in Gram-negative bacteria. ${ }^{4,10}$ This active knowledge can be used towards under-

Table I Crucial Omps studied in different bacteria

\begin{tabular}{|c|c|}
\hline Protein & Pathogens \\
\hline OmpX, ${ }^{14}$ OmpA, ${ }^{15-17}$ OmpT, ${ }^{18}$ Tsx, ${ }^{19} \mathrm{FadL},{ }^{20} \mathrm{OmpF},{ }^{7,8,21,22}$ OmpC, ${ }^{23-31} \mathrm{PhoE},{ }^{32} \mathrm{LamB},{ }^{33,34} \mathrm{BtuB}^{35}{ }^{35} \mathrm{FepA},{ }^{36} \mathrm{FhuA},{ }^{37,38} \mathrm{TolC}$ & Escherichia coli \\
\hline Omp36, ${ }^{3,31,39-41}$ Omp35 $35^{8,31,39,40,42}$ & Enterobacter aerogenes \\
\hline OmpE36, ${ }^{43} \mathrm{OmpE} 35^{8}$ & Enterobacter cloacae \\
\hline OmpK36, ${ }^{30,31,44} \mathrm{OmpK} 35^{8,30,31,44}$ & Klebsiella pneumoniae \\
\hline MOMP, ${ }^{45-49} \mathrm{Omp} 50^{49,50}$ & Campylobacter jejuni \\
\hline$(\mathrm{Occ} A B \mathrm{~B}-\mathrm{OccAB} 5),{ }^{51} \mathrm{rOprD},{ }^{52} \mathrm{CarO},{ }^{53,54} \mathrm{Omp} 25^{55}$ & Acinetobacter baumannii \\
\hline NspA, ${ }^{56}$ OpcA, ${ }^{57}$ NalP 58 & Neisseria meningitidis \\
\hline $\mathrm{Hia}^{59}$ & Haemophilus influenzae \\
\hline CymA 60,61 & Klebsiella oxytoca \\
\hline$\alpha$-hemolysin $\sin ^{62,63}$ & Staphylococcus aureus \\
\hline$M_{s p A}^{64}$ & Mycobacterium smegmatis \\
\hline ScrY 65 & Salmonella typhimurium \\
\hline OmpPstl, ${ }^{66,67}$ OmpPst2 ${ }^{67}$ & Providencia stuartii \\
\hline (OccDI (OprD), OccD2 (OpdC), OccD3 (OpdP), OccD4 (OpdT), OccD5 (Opdl), OccD6 (OprQ), OccD7 (OpdB), & Pseudomonas aeruginosa \\
\hline \multicolumn{2}{|l|}{ OccD8 $($ Opd $))^{8,68-76}$} \\
\hline \multicolumn{2}{|l|}{ (OccKI (OpdK), Occk2 (OpdF), OccK3 (OpdO), OccK4 (OpdL), OccK5 (OpdH), OccK6 (OpdQ), OccK7 (OpdD), } \\
\hline \multicolumn{2}{|l|}{ OccK8 $(\text { OprE) })^{8,73,74,77-84}$} \\
\hline OprP, ${ }^{75,85-88} \mathrm{OprO}^{87}$ & \\
\hline
\end{tabular}

Note: Copyright @2017. Dove Medical Press. Adapted from Ghai I, Ghai S. Exploring bacterial outer membrane barrier to combat bad bugs. Infect Drug Resist. $2017 ; 10: 261-273 .^{8}$ 
Table 2 Conclusive investigations with different Omps studied in pathogens

\begin{tabular}{|c|c|c|}
\hline Decisive investigation & Omp & Pathogens \\
\hline Studied interaction of $\beta$-lactam molecule meropenem using ETP. ${ }^{89}$ & OmpF & Escherichia coli \\
\hline Studied interaction of ampicillin, penicilloic-acid, and benzylpenicillin with Omp using ETP., ${ }^{7,123}$ & OmpF & E. coli \\
\hline Studied and showed effect of access resistance in Omp using ETP. ${ }^{22}$ & OmpF & E. coli \\
\hline Studied transport of divalent metal ions and their effect on conductance and selectivity of Omp. ${ }^{90}$ & OmpF & E. coli \\
\hline $\begin{array}{l}\text { Studied the effect of salts of divalent cations on the Omp conductance, particularly the role of the } \\
\text { electrolyte and the counterion accumulation induced by the Omp charges, and other effects not found } \\
\text { in salts of monovalent cations using ETP.91 }\end{array}$ & OmpF & E. coli \\
\hline $\begin{array}{l}\text { Studied effect of divalent cations toward } \mathrm{pH} \text { sensitivity of Omp via inducing the pKa shift of key acidic } \\
\text { residues using ETP. }{ }^{92}\end{array}$ & OmpF & E. coli \\
\hline Studied mechanism of selectivity inversion in the Omp using ETP. ${ }^{93}$ & OmpF & E. coli \\
\hline Studied ciprofloxacin permeation pathways across Omp using MS. ${ }^{94}$ & OmpC & E. coli \\
\hline Studied recombinant form of the Omp and demonstrated the monomeric nature of Omp using ETP. ${ }^{95}$ & OmpG & E. coli \\
\hline Determined the X-ray crystal structure of the Omp. ${ }^{96}$ & OmpG & E. coli \\
\hline Determined the crystal structure of the Omp in two dimensions. ${ }^{97}$ & OmpG & E. coli \\
\hline Studied mechanism of folding of Omp in detergent solution. ${ }^{98}$ & OmpG & E. coli \\
\hline $\begin{array}{l}\text { Studied structural configuration of different Omps and measured penetration rates of different } \\
\beta \text {-lactams using LSA.9 }\end{array}$ & OmpA & E. coli \\
\hline Studied binding regions of Omp using site-directed fluorescence study. ${ }^{17}$ & OmpA & E. coli \\
\hline Studied function of Omp in stress survival using microbiological assay. ${ }^{16}$ & OmpA & E. coli \\
\hline Studied crystal structure of Omp and further explained possible mechanisms of virulence. ${ }^{14}$ & OmpX & E. coli \\
\hline Studied the Omp behavior and described the effect of expanded channel protein using ETP. ${ }^{100}$ & FhuA & E. coli \\
\hline Studied transfer of DNA via Omp using LSA. ${ }^{101}$ & FhuA & E. coli \\
\hline $\begin{array}{l}\text { Studied structural parameters of Omp using size exclusion chromatography, sedimentation equilibrium, } \\
\text { and velocity experiments. }{ }^{102}\end{array}$ & FhuA & E. coli \\
\hline $\begin{array}{l}\text { Studied structures and the interaction of proteins and protein subdomains, and also demonstrated the } \\
\text { role of the Omp in outer membrane permeability. }{ }^{103}\end{array}$ & FhuA, & E. coli \\
\hline Demonstrated $\mathrm{Fe}^{3+}$ as ferrichrome complex transport through the outer membrane..$^{104}$ & FhuA & E. coli \\
\hline $\begin{array}{l}\text { Studied interaction of } \beta \text {-lactam molecules ertapenem, cefepime, and cefoxitin, using ETP and MIC } \\
\text { assay }{ }^{67}\end{array}$ & $\begin{array}{l}\text { OmpPstl } \\
\text { and } \\
\text { OmpPst2 }\end{array}$ & Providencia stuartii \\
\hline $\begin{array}{l}\text { Studied Omp structure, including function of surface-exposed loops and Omp interaction with } \\
\text { membrane components (e.g., LPS) using conventional ETP and MS. }{ }^{66}\end{array}$ & $\begin{array}{l}\text { OmpPstl } \\
\text { and } \\
\text { OmpPst2 }\end{array}$ & P. stuartii \\
\hline Studied role of Omp in carbapenem transport across outer membrane using ETP and LSA. ${ }^{105}$ & OmpPstl & P. stuartii \\
\hline Described and explained biophysical properties of the Omp. ${ }^{45}$ & MOMP & Campylobacter jejuni \\
\hline $\begin{array}{l}\text { Studied and confirmed conformational analyses showing the presence of a native trimeric state } \\
\text { generated by association of the three folded monomers, and further compared the stability with that of } \\
\text { Escherichia coli porins. }{ }^{46}\end{array}$ & MOMP & C. jejuni \\
\hline Studied translocation of short poly-arginines across Omp using ETP. ${ }^{41}$ & MOMP & C. jejuni \\
\hline $\begin{array}{l}\text { Studied the three-dimensional structure of Omp and elucidated the underlying molecular mechanisms } \\
\text { using X-ray diffraction. }{ }^{47}\end{array}$ & MOMP & C. jejuni \\
\hline $\begin{array}{l}\text { Studied sequence polymorphism and showed secondary structures, and surface-exposed } \\
\text { conformational epitopes of the Omp. }{ }^{106}\end{array}$ & MOMP & C. jejuni \\
\hline $\begin{array}{l}\text { Studied channel-forming properties of Omp as trimer and monomer using ETP, and transition of trimer } \\
\text { to monomer using light scattering; further examined the secondary structures of these two molecular } \\
\text { states by infra-red spectroscopy. }{ }^{48}\end{array}$ & MOMP & C. jejuni \\
\hline $\begin{array}{l}\text { Studied different environmental regulation factors controlling Omp expression in Escherichia coli using } \\
\text { fluorescent spectroscopy. }{ }^{49}\end{array}$ & $\begin{array}{l}\text { MOMP and } \\
\text { Omp50 }\end{array}$ & C. jejuni \\
\hline $\begin{array}{l}\text { Studied pore-forming ability of the Omp and performed biophysical characterization using conventional } \\
\text { ETP. } .^{50}\end{array}$ & Omp50 & C. jejuni \\
\hline $\begin{array}{l}\text { Studied key residues in the channel constriction and their effect on substrate specificity of the Omp } \\
\text { using ETP and MS. }{ }^{107}\end{array}$ & $\begin{array}{l}\text { OprP and } \\
\text { OprO }\end{array}$ & Pseudomonas aeruginosa \\
\hline Studied transport of fosfomycin via Omp using ETP. ${ }^{108}$ & $\begin{array}{l}\text { OprP and } \\
\text { OprO }\end{array}$ & P. aeruginosa \\
\hline $\begin{array}{l}\text { Showed decreased Omp production to be one of the contributing factors for carbapenem } \\
\text { heteroresistance. }{ }^{109}\end{array}$ & OprD & P. aeruginosa \\
\hline Studied role of Omp in increasing MICs of carbapenems in clinical isolate. ${ }^{110}$ & OprD & P. aeruginosa \\
\hline
\end{tabular}


Table 2 (Continued)

\begin{tabular}{|c|c|c|}
\hline Decisive investigation & Omp & Pathogens \\
\hline Studied Omp levels in carbapenem-resistant isolates using real-time polymerase chain reaction. ${ }^{\prime \prime \prime}$ & OprD & P. aeruginosa \\
\hline $\begin{array}{l}\text { Studied and characterized discrepant carbapenem susceptibility profile including alterations in outer } \\
\text { membrane permeability. }{ }^{1 / 2}\end{array}$ & OprD & P. aeruginosa \\
\hline $\begin{array}{l}\text { Studied in vitro activity of ceftazidime-avibactam and ceftolozane-tazobactam against meropenem- } \\
\text { resistant isolates using MIC.13 }\end{array}$ & OprD & P. aeruginosa \\
\hline Studied and identified unique in-frame deletions in Omp among clinical isolates. ${ }^{114}$ & OprD & P. aeruginosa \\
\hline Studied variations of Omp dominating in imipenem-resistant isolates. ${ }^{1 / 5}$ & OprD & P. aeruginosa \\
\hline $\begin{array}{l}\text { Developed whole-cell-based assay, system to characterize the structure of Omp and its role in } \\
\text { permeation for a set of novel carbapenem analogs. }{ }^{16}\end{array}$ & OprD & P. aeruginosa \\
\hline $\begin{array}{l}\text { Studied effect of Omp polymorphisms, particularly the amino acid substitution at codon } 170 \text { toward } \\
\text { carbapenem resistance. }{ }^{177}\end{array}$ & OprD & P. aeruginosa \\
\hline Studied the impact of single amino acid substitutions in Omp on carbapenem resistant strains. ${ }^{118}$ & OprD & P. aeruginosa \\
\hline $\begin{array}{l}\text { Studied and showed incapacitating mutation and decreased expression of Omp to be one of the factors } \\
\text { contributing toward imipenem and meropenem resistance. }{ }^{19}\end{array}$ & OprD & P. aeruginosa \\
\hline Studied and showed the role of Omp in 70 different carbapenem-resistant clinical isolates. ${ }^{120}$ & OprD & P. aeruginosa \\
\hline $\begin{array}{l}\text { Studied channel-forming properties and other physicochemical properties of Omp using ETP and mass } \\
\text { spectrometry. }{ }^{55}\end{array}$ & $\begin{array}{l}\text { CarO and } \\
\text { Omp25 }\end{array}$ & Acinetobacter baumannii \\
\hline $\begin{array}{l}\text { Studied L-ornithine uptake via Omp, also showed L-ornithine's effect over pathogen sensitivity to } \\
\text { imipenem. }\end{array}$ & CarO & A. baumannii \\
\hline
\end{tabular}

standing the effect of outer membrane influx in antibiotic resistance in Gram-negative bacteria which can be further used for future antibiotic drug development.

\section{Conclusion}

In this review, we continued to explore different outer membrane proteins by extending and recapitulating the progressive systematic evidence elucidating the role of Omps in solute membrane permeability in Gram-negative bacteria. ${ }^{7.8}$ Bacterial membrane transport is a multifaceted process that is strongly controlled by a complicated network of activities that sense and respond to external stress. ${ }^{8}$ Significantly, bacteria make use of these cultured controlled cascades that perceive and distinguish different toxic compounds and respond by triggering various resistance mechanisms, including modification of specific Omps. ${ }^{4-6,13,122}$ Membrane penetrability, which further, along with added resistance mechanisms, including drug inactivation or target modification, has become one of the major problems in effective antibiotic therapy. Effective information regarding the role of effective Omps in substrate uptake and further explaining their structural relationship toward the uptake, highlights the capability of the scientific community in the direction of understanding the bacterial resistance machinery generated mainly via modification of membrane permeability. ${ }^{48,13,122}$ Understanding translocation via Omps can be regarded as a first step toward defining a pathway of an antibiotic specific to its target. Consequently, interpretation of antibiotic translocation through Omps is crucial for understanding the connection between influx and activities in bacteria. The function of the general diffusion Omp has been well studied based on Omp characteristics, alteration, and mutations. We also tried to combine data from different studies concerning the Omps. Our understanding of the structure of the pore-forming complex has been extremely improved over the last decade with emergence of the computational approach, crystallographic data from X-rays, electron microscopy, mass spectrometry, and electrophysiology. However, significant key knowledge regarding the transformation of outer membrane pores' transportation mechanism is still required to further elaborate their conditional role in antibiotic/antimicrobial transport. The molecular basis of antibiotic transport via specific porins is presently open to interpretation, and additional rigorous studies are required to give insight into the structural-activity relationship between Omp geometry and antibiotic transport. Collectively, the current and previous ${ }^{8}$ data can be employed in an effort to explain substrates, especially antibiotic uptake pathways, and may provide insights into molecular mechanisms that could enable rational drug design to enhance permeation and provide novel strategies to solve the "impermeability" issue of antibiotic resistance.

\section{Acknowledgments}

The publication of this article was funded by the Open Access fund of Leibniz Universität Hannover. The authors sincerely thank their research groups for their support.

\section{Disclosure}

The authors report no conflicts of interest in this work. 


\section{References}

1. Martínez-Martínez L, Calvo J. El problema creciente de la resistencia antibiótica en bacilos gramnegativos: situación actual [The growing problem of antibiotic resistance in clinically relevant Gram-negative bacteria: current situation]. Enfermedades Infecciosas y Microbiología Clínica. 2010;28(Supplement 2):25-31. Spanish.

2. Pages JM. [Antibiotic transport and membrane permeability: new insights to fight bacterial resistance]. Biol Aujourdhui. 2017;211(2): 149-154. French.

3. Thiolas A, Bornet C, Davin-Regli A, Pages JM, Bollet C. Resistance to imipenem, cefepime, and cefpirome associated with mutation in Omp36 osmoporin of Enterobacter aerogenes. Biochem Biophys Res Commun. 2004;317(3):851-856.

4. Nikaido H. Molecular basis of bacterial outer membrane permeability revisited. Microbiol Mol Biol Rev. 2003;67(4):593-656.

5. Pages JM, James CE, Winterhalter M. The porin and the permeating antibiotic: a selective diffusion barrier in Gram-negative bacteria. Nat Rev Microbiol. 2008;6(12):893-903.

6. Winterhalter M, Ceccarelli M. Physical methods to quantify small antibiotic molecules uptake into Gram-negative bacteria. Eur JPharm Biopharm. 2015;95(Pt A):63-67.

7. Ghai I. Quantifying the Flux of Charged Molecules through Bacterial Membrane Proteins. Bremen: IRC-Library, Information Resource Center der Jacobs University Bremen; 2017.

8. Ghai I, Ghai S. Exploring bacterial outer membrane barrier to combat bad bugs. Infect Drug Resist. 2017;10:261-273.

9. Kostyanev T, Bonten MJ, O'Brien S, et al. The Innovative Medicines Initiative's New Drugs for Bad Bugs programme: European publicprivate partnerships for the development of new strategies to tackle antibiotic resistance. J Antimicrob Chemother. 2016;71(2):290-295.

10. Stavenger RA, Winterhalter M. TRANSLOCATION project: how to get good drugs into bad bugs. Sci Transl Med. 2014;6(228):228ed227.

11. Vergalli J, Dumont E, Cinquin B, et al. Fluoroquinolone structure and translocation flux across bacterial membrane. Sci Rep. 2017;7(1):9821.

12. Delcour AH. Outer membrane permeability and antibiotic resistance. Biochim Biophys Acta. 2009;1794(5):808-816.

13. Benz R. Structure and function of porins from gram-negative bacteria. Annu Rev Microbiol. 1988;42:359-393.

14. Vogt J, Schulz GE. The structure of the outer membrane protein OmpX from Escherichia coli reveals possible mechanisms of virulence. Structure. 1999;7(10):1301-1309.

15. Pautsch A, Schulz GE. Structure of the outer membrane protein A transmembrane domain. Nat Struct Biol. 1998;5(11):1013-1017.

16. Wang Y. The function of OmpA in Escherichia coli. Biochem Biophys Res Commun. 2002;292(2):396-401.

17. Qu J, Behrens-Kneip S, Holst O, Kleinschmidt JH. Binding regions of outer membrane protein $\mathrm{A}$ in complexes with the periplasmic chaperone Skp. A site-directed fluorescence study. Biochemistry. 2009;48(22):4926-4936.

18. Vandeputte-Rutten L, Kramer RA, Kroon J, Dekker N, Egmond MR, Gros P. Crystal structure of the outer membrane protease OmpT from Escherichia coli suggests a novel catalytic site. EMBO J. 2001;20(18):5033-5039.

19. Ye J, van den Berg B. Crystal structure of the bacterial nucleoside transporter Tsx. EMBO J. 2004;23(16):3187-3195.

20. van den Berg B, Black PN, Clemons WM Jr, Rapoport TA. Crystal structure of the long-chain fatty acid transporter FadL. Science. 2004;304(5676):1506-1509.

21. Cowan SW, Schirmer T, Rummel G, et al. Crystal structures explain functional properties of two E. coli porins. Nature. 1992;358(6389): 727-733.

22. Alcaraz A, López ML, Queralt-Martín M, Aguilella VM. Ion transport in confined geometries below the nanoscale: access resistance dominates protein channel conductance in diluted solutions. ACS Nano. 2017;11(10):10392-10400
23. Acosta Gutierrez S, Bodrenko I, Scorciapino MA, Ceccarelli M. Macroscopic electric field inside water-filled biological nanopores. Phys Chem Chem Phys. 2016;18(13):8855-8864.

24. Lovelle M, Mach T, Mahendran KR, Weingart H, Winterhalter M, Gameiro P. Interaction of cephalosporins with outer membrane channels of Escherichia coli. Revealing binding by fluorescence quenching and ion conductance fluctuations. Phys Chem Chem Phys. 2011;13(4):1521-1530.

25. Mahendran KR, Kreir M, Weingart H, Fertig N, Winterhalter M. Permeation of antibiotics through Escherichia coli OmpF and OmpC porins: screening for influx on a single-molecule level. J Biomol Screen. 2010;15(3):302-307.

26. Pinet E, Franceschi C, Davin-Regli A, Zambardi G, Pages JM. Role of the culture medium in porin expression and piperacillintazobactam susceptibility in Escherichia coli. J Med Microbiol. 2015;64(11):1305-1314

27. Scorciapino MA, D’Agostino T, Acosta-Gutierrez S, Malloci G, Bodrenko I, Ceccarelli M. Exploiting the porin pathway for polar compound delivery into Gram-negative bacteria. Future Med Chem. 2016;8(10):1047-1062.

28. Liu N, Samartzidou H, Lee KW, Briggs JM, Delcour AH. Effects of pore mutations and permeant ion concentration on the spontaneous gating activity of OmpC porin. Protein Eng. 2000;13(7): 491-500

29. Lou H, Chen M, Black SS, et al. Altered antibiotic transport in OmpC mutants isolated from a series of clinical strains of multi-drug resistant E. coli. PLoS One. 2011;6(10):e25825.

30. Pages JM, Peslier S, Keating TA, Lavigne JP, Nichols WW. Role of the outer membrane and porins in susceptibility of beta-lactamaseproducing enterobacteriaceae to ceftazidime-avibactam. Antimicrob Agents Chemother. 2015;60(3):1349-1359.

31. Sugawara E, Kojima S, Nikaido H. Klebsiella pneumoniae major porins OmpK35 and OmpK36 allow more efficient diffusion of beta-lactams than their Escherichia coli homologs OmpF and OmpC. J Bacteriol. 2016;198(23):3200-3208.

32. Monier R. [Wilhelm Bernhard (1920-1978)]. Biomedicine. 1979;30(1): 16-28. French.

33. Meyer JE, Hofnung M, Schulz GE. Structure of maltoporin from Salmonella typhimurium ligated with a nitrophenyl-maltotrioside. J Mol Biol. 1997;266(4):761-775.

34. Schirmer T, Keller TA, Wang YF, Rosenbusch JP. Structural basis for sugar translocation through maltoporin channels at 3.1 A resolution. Science. 1995;267(5197):512-514.

35. Chimento DP, Mohanty AK, Kadner RJ, Wiener MC. Substrateinduced transmembrane signaling in the cobalamin transporter BtuB. Nat Struct Biol. 2003;10(5):394-401.

36. Buchanan SK, Smith BS, Venkatramani L, et al. Crystal structure of the outer membrane active transporter FepA from Escherichia coli. Nat Struct Biol. 1999;6(1):56-63.

37. Ferguson AD, Hofmann E, Coulton JW, Diederichs K, Welte W. Siderophore-mediated iron transport: crystal structure of FhuA with bound lipopolysaccharide. Science. 1998;282(5397): 2215-2220.

38. Thakur AK, Larimi MG, Gooden K, Movileanu L. Aberrantly large single-channel conductance of polyhistidine arm-containing protein nanopores. Biochemistry. 2017;56(36):4895-4905.

39. Bornet C, Davin-Regli A, Bosi C, Pages JM, Bollet C. Imipenem resistance of enterobacter aerogenes mediated by outer membrane permeability. J Clin Microbiol. 2000;38(3):1048-1052.

40. Lavigne JP, Sotto A, Nicolas-Chanoine MH, Bouziges N, Pages JM, Davin-Regli A. An adaptive response of Enterobacter aerogenes to imipenem: regulation of porin balance in clinical isolates. Int J Antimicrob Agents. 2013;41(2):130-136.

41. James CE, Mahendran KR, Molitor A, et al. How beta-lactam antibiotics enter bacteria: a dialogue with the porins. PLoS One. 2009;4(5):e5453. 
42. Bornet C, Saint N, Fetnaci L, et al. Omp35, a new Enterobacter aerogenes porin involved in selective susceptibility to cephalosporins. Antimicrob Agents Chemother. 2004;48(6):2153-2158.

43. Arunmanee W, Pathania M, Solovyova AS, et al. Gram-negative trimeric porins have specific LPS binding sites that are essential for porin biogenesis. Proc Natl Acad Sci U S A. 2016;113(34):E5034-5043.

44. Castanheira M, Mendes RE, Sader HS. Low frequency of ceftazidimeavibactam resistance among enterobacteriaceae isolates carrying blaKPC collected in U.S. hospitals from 2012 to 2015. Antimicrob Agents Chemother. 2017;61(3).

45. Ferrara LG, Wallat GD, Moynie L, et al. MOMP from Campylobacter jejuni is a trimer of 18-stranded beta-barrel monomers with a $\mathrm{Ca} 2+$ ion bound at the constriction zone. J Mol Biol. 2016;428(22): 4528-4543.

46. Bolla JM, Loret E, Zalewski M, Pages JM. Conformational analysis of the Campylobacter jejuni porin. J Bacteriol. 1995;177(15):4266-4271.

47. Bolla JM, Saint N, Labesse G, Pages JM, Dumas C. Crystallization and preliminary crystallographic studies of MOMP (major outer membrane protein) from Campylobacter jejuni. Acta Crystallogr D Biol Crystallogr. 2004;60(Pt 12 Pt 2):2349-2351.

48. De E, Jullien M, Labesse G, Pages JM, Molle G, Bolla JM. MOMP (major outer membrane protein) of Campylobacter jejuni; a versatile pore-forming protein. FEBS Lett. 2000;469(1):93-97.

49. Dedieu L, Pages JM, Bolla JM. Environmental regulation of Campylobacter jejuni major outer membrane protein porin expression in Escherichia coli monitored by using green fluorescent protein. $\mathrm{Appl}$ Environ Microbiol. 2002;68(9):4209-4215.

50. Bolla JM, De E, Dorez A, Pages JM. Purification, characterization and sequence analysis of Omp50, a new porin isolated from Campylobacter jejuni. Biochem J. 2000;352 Pt 3:637-643.

51. Zahn M, Bhamidimarri Satya P, Baslé A, Winterhalter M, van den Berg B. Structural insights into outer membrane permeability of Acinetobacter baumannii. Structure. 2016;24(2):221-231.

52. Catel-Ferreira M, Nehme R, Molle V, et al. Deciphering the function of the outer membrane protein OprD homologue of Acinetobacter baumannii. Antimicrob Agents Chemother. 2012;56(7):3826-3832.

53. Catel-Ferreira M, Coadou G, Molle V, et al. Structure-function relationships of $\mathrm{CarO}$, the carbapenem resistance-associated outer membrane protein of Acinetobacter baumannii. J Antimicrob Chemother. 2011;66(9):2053-2056.

54. Zahn M, D’Agostino T, Eren E, Basle A, Ceccarelli M, van den Berg B. Small-molecule transport by CarO, an abundant eight-stranded beta-barrel outer membrane protein from Acinetobacter baumannii. J Mol Biol. 2015;427(14):2329-2339.

55. Siroy A, Molle V, Lemaitre-Guillier C, et al. Channel formation by $\mathrm{CarO}$, the carbapenem resistance-associated outer membrane protein of Acinetobacter baumannii. Antimicrob Agents Chemother. 2005;49(12):4876-4883.

56. Vandeputte-Rutten L, Bos MP, Tommassen J, Gros P. Crystal structure of Neisserial surface protein A (NspA), a conserved outer membrane protein with vaccine potential. J Biol Chem. 2003;278(27):24825-24830.

57. Prince SM, Achtman M, Derrick JP. Crystal structure of the OpcA integral membrane adhesin from Neisseria meningitidis. Proc Natl Acad Sci U S A. 2002;99(6):3417-3421.

58. Oomen CJ, van Ulsen P, van Gelder P, Feijen M, Tommassen J, Gros P. Structure of the translocator domain of a bacterial autotransporter. EMBO J. 2004;23(6):1257-1266.

59. Meng G, Surana NK, St Geme JW 3rd, Waksman G. Structure of the outer membrane translocator domain of the Haemophilus influenzae Hia trimeric autotransporter. EMBO J. 2006;25(11):2297-2304.

60. van den Berg B, Prathyusha Bhamidimarri S, Dahyabhai Prajapati J, Kleinekathofer U, Winterhalter M. Outer-membrane translocation of bulky small molecules by passive diffusion. Proc Natl Acad Sci USA. 2015;112(23):E2991-E2999.

61. Bhamidimarri SP, Prajapati JD, van den Berg B, Winterhalter M, Kleinekathofer U. Role of electroosmosis in the permeation of neutral molecules: CymA and cyclodextrin as an example. Biophys J. 2016;110(3):600-611.
62. Montoya M, Gouaux E. Beta-barrel membrane protein folding and structure viewed through the lens of alpha-hemolysin. Biochim Biophys Acta. 2003;1609(1):19-27.

63. Song L, Hobaugh MR, Shustak C, Cheley S, Bayley H, Gouaux JE. Structure of staphylococcal alpha-hemolysin, a heptameric transmembrane pore. Science. 1996;274(5294):1859-1866.

64. Faller M, Niederweis M, Schulz GE. The structure of a mycobacterial outer-membrane channel. Science. 2004;303(5661):1189-1192.

65. Forst D, Welte W, Wacker T, Diederichs K. Structure of the sucrosespecific porin ScrY from Salmonella typhimurium and its complex with sucrose. Nat Struct Biol. 1998;5(1):37-46.

66. Tran QT, Maigre L, D’Agostino T, et al. Porin flexibility in Providencia stuartii: cell-surface-exposed loops L5 and L7 are markers of Providencia porin OmpPst1. Res Microbiol. 2017;168(8):685-699.

67. Tran QT, Mahendran KR, Hajjar E, et al. Implication of porins in beta-lactam resistance of Providencia stuartii. J Biol Chem. 2010;285(42):32273-32281.

68. Eren E, Parkin J, Adelanwa A, et al. Toward understanding the outer membrane uptake of small molecules by Pseudomonas aeruginosa. $J$ Biol Chem. 2013;288(17):12042-12053.

69. Liu J, Wolfe AJ, Eren E, et al. Cation selectivity is a conserved feature in the OccD subfamily of Pseudomonas aeruginosa. Biochim Biophys Acta. 2012;1818(11):2908-2916.

70. Biswas S, Mohammad MM, Patel DR, Movileanu L, van den Berg B. Structural insight into OprD substrate specificity. Nat Struct Mol Biol. 2007;14(11):1108-1109.

71. Huang H, Hancock RE. The role of specific surface loop regions in determining the function of the imipenem-specific pore protein OprD of Pseudomonas aeruginosa. J Bacteriol. 1996;178(11):3085-3090.

72. Samanta S, Scorciapino MA, Ceccarelli M. Molecular basis of substrate translocation through the outer membrane channel OprD of Pseudomonas aeruginosa. Phys Chem Chem Phys. 2015;17(37):23867-23876.

73. Eren E, Vijayaraghavan J, Liu J, et al. Substrate specificity within a family of outer membrane carboxylate channels. PLoS Biol. 2012;10(1): e1001242.

74. Liu J, Eren E, Vijayaraghavan J, et al. OccK channels from Pseudomonas aeruginosa exhibit diverse single-channel electrical signatures but conserved anion selectivity. Biochemistry. 2012;51(11):2319-2330.

75. Modi N, Benz R, Hancock RE, Kleinekathofer U. Modeling the ion selectivity of the phosphate specific channel OprP. J Phys Chem Lett. 2012;3(23):3639-3645.

76. Soundararajan G, Bhamidimarri SP, Winterhalter M. Understanding carbapenem translocation through OccD3 (OpdP) of Pseudomonas aeruginosa. ACS Chem Biol. 2017;12(6):1656-1664.

77. Chalhoub H, Pletzer D, Weingart H, et al. Mechanisms of intrinsic resistance and acquired susceptibility of Pseudomonas aeruginosa isolated from cystic fibrosis patients to temocillin, a revived antibiotic. Sci Rep. 2017;7:40208.

78. Cheneke BR, Indic M, van den Berg B, Movileanu L. An outer membrane protein undergoes enthalpy- and entropy-driven transitions. Biochemistry. 2012;51(26):5348-5358.

79. Cheneke BR, van den Berg B, Movileanu L. Analysis of gating transitions among the three major open states of the OpdK channel. Biochemistry. 2011;50(22):4987-4997.

80. Pothula KR, Dhanasekar NN, Lamichhane U, et al. Single residue acts as gate in OccK channels. J Phys Chem B. 2017;121(12):2614-2621.

81. Pothula KR, Kleinekathofer U. Theoretical analysis of ion conductance and gating transitions in the OpdK (OccK1) channel. Analyst. 2015;140(14):4855-4864.

82. Samanta S, D'Agostino T, Ghai I, et al. How to get large drugs through small pores? Exploiting the porins pathway in Pseudomonas Aeruginosa. Biophys J. 2017;112(3 Supplement 1):416a.

83. Hajjar E, Mahendran KR, Kumar A, et al. Bridging timescales and length scales: from macroscopic flux to the molecular mechanism of antibiotic diffusion through porins. Biophys J. 2010;98(4):569-575.

84. Tamber S, Maier E, Benz R, Hancock RE. Characterization of OpdH, a Pseudomonas aeruginosa porin involved in the uptake of tricarboxylates. J Bacteriol. 2007;189(3):929-939. 
85. Modi N, Barcena-Uribarri I, Bains M, Benz R, Hancock RE, Kleinekathofer U. Role of the central arginine R133 toward the ion selectivity of the phosphate specific channel OprP: effects of charge and solvation. Biochemistry. 2013;52(33):5522-5532.

86. Modi N, Barcena-Uribarri I, Bains M, Benz R, Hancock RE, Kleinekathofer $\mathrm{U}$. Tuning the affinity of anion binding sites in porin channels with negatively charged residues: molecular details for OprP. ACS Chem Biol. 2015;10(2):441-451.

87. Modi N, Ganguly S, Barcena-Uribarri I, Benz R, van den Berg B, Kleinekathofer U. Structure, dynamics, and substrate specificity of the OprO porin from Pseudomonas aeruginosa. Biophys J. 2015;109(7): 1429-1438.

88. Pongprayoon P, Beckstein O, Wee CL, Sansom MS. Simulations of anion transport through OprP reveal the molecular basis for high affinity and selectivity for phosphate. Proc Natl Acad Sci USA. 2009; 106(51):21614-21618.

89. Bodrenko IV, Wang J, Salis S, Winterhalter M, Ceccarelli M. Sensing single molecule penetration into nanopores: pushing the time resolution to the diffusion limit. ACS Sens. 2017;2(8):1184-1190.

90. Garcia-Gimenez E, Alcaraz A, Aguilella VM. Divalent metal ion transport across large biological ion channels and their effect on conductance and selectivity. Biochem Res Int. 2012;2012:245786.

91. Garcia-Gimenez E, Lopez ML, Aguilella VM, Alcaraz A. Linearity, saturation and blocking in a large multiionic channel: divalent cation modulation of the OmpF porin conductance. Biochem Biophys Res Commun. 2011;404(1):330-334.

92. Queralt-Martin M, Garcia-Gimenez E, Mafe S, Alcaraz A. Divalent cations reduce the $\mathrm{pH}$ sensitivity of OmpF channel inducing the $\mathrm{pK}(\mathrm{a})$ shift of key acidic residues. Phys Chem Chem Phys. 2011;13(2):563-569.

93. Alcaraz A, Nestorovich EM, Lopez ML, Garcia-Gimenez E, Bezrukov SM, Aguilella VM. Diffusion, exclusion, and specific binding in a large channel: a study of OmpF selectivity inversion. Biophys $J$. 2009;96(1):56-66.

94. Prajapati JD, Fernández Solano CJ, Winterhalter M, Kleinekathöfer U. Characterization of ciprofloxacin permeation pathways across the porin OmpC using metadynamics and a string method. J Chem Theory Comput. 2017;13(9):4553-4566.

95. Conlan S, Zhang Y, Cheley S, Bayley H. Biochemical and biophysical characterization of OmpG: a monomeric porin. Biochemistry. 2000;39(39):11845-11854

96. Subbarao GV, van den Berg B. Crystal structure of the monomeric porin OmpG. J Mol Biol. 2006;360(4):750-759.

97. Behlau M, Mills DJ, Quader H, Kuhlbrandt W, Vonck J. Projection structure of the monomeric porin OmpG at $6 \mathrm{~A}$ resolution. $J$ Mol Biol. 2001;305(1):71-77.

98. Conlan S, Bayley H. Folding of a monomeric porin, OmpG, in detergent solution. Biochemistry. 2003;42(31):9453-9465.

99. Nitzan Y, Deutsch EB, Pechatnikov I. Diffusion of beta-lactam antibiotics through oligomeric or monomeric porin channels of some gram-negative bacteria. Curr Microbiol. 2002;45(6):446-455.

100. Liu Z, Ghai I, Winterhalter M, Schwaneberg U. Engineering enhanced pore sizes using FhuA Delta1-160 from E. coli outer membrane as template. ACS Sens. 2017;2(11):1619-1626.

101. Plancon L, Chami M, Letellier L. Reconstitution of FhuA, an Escherichia coli outer membrane protein, into liposomes. Binding of phage T5 to Fhua triggers the transfer of DNA into the proteoliposomes. J Biol Chem. 1997;272(27):16868-16872.

102. Bonhivers M, Plancon L, Ghazi A, et al. FhuA, an Escherichia coli outer membrane protein with a dual function of transporter and channel which mediates the transport of phage DNA. Biochimie. 1998;80(5-6):363-369.

103. Braun V, Endriss F. Energy-coupled outer membrane transport proteins and regulatory proteins. Biometals. 2007;20(3-4):219-231.

104. Braun V, Killmann H, Benz R. Energy-coupled transport through the outer membrane of Escherichia coli small deletions in the gating loop convert the FhuA transport protein into a diffusion channel. FEBS Lett. 1994;346(1):59-64.
105. Bajaj H, Tran QT, Mahendran KR, et al. Antibiotic uptake through membrane channels: role of Providencia stuartii OmpPst1 porin in carbapenem resistance. Biochemistry. 2012;51(51):10244-10249.

106. Zhang Q, Meitzler JC, Huang S, Morishita T. Sequence polymorphism, predicted secondary structures, and surface-exposed conformational epitopes of Campylobacter major outer membrane protein. Infect Immun. 2000;68(10):5679-5689.

107. Ganguly S, Kesireddy A, Barcena-Uribarri I, Kleinekathofer U, Benz R. Conversion of OprO into an OprP-like channel by exchanging key residues in the channel constriction. Biophys J. 2017;113(4): 829-834.

108. Citak F, Ghai I, Rosenkotter F, Benier L, Winterhalter M, Wagner R. Probing transport of fosfomycin through substrate specific OprO and OprP from Pseudomonas aeruginosa. Biochem Biophys Res Commun. 2018;495(1):1454-1460.

109. He J, Jia X, Yang S, et al. Heteroresistance to carbapenems in invasive pseudomonas aeruginosa infections. Int J Antimicrob Agents. Epub 2017 Nov 7.

110. Hirabayashi A, Kato D, Tomita Y, et al. Risk factors for and role of OprD protein in increasing minimal inhibitory concentrations of carbapenems in clinical isolates of Pseudomonas aeruginosa. $\mathrm{J} \mathrm{Med}$ Microbiol. 2017;66(11):1562-1572.

111. Agah Terzi H, Kulah C, Riza Atasoy A, Hakki Ciftci I. Investigation of OprD porin protein levels in carbapenem-resistant Pseudomonas aeruginosa isolates. Jundishapur J Microbiol. 2015;8(12):e25952.

112. Pragasam AK, Raghanivedha M, Anandan S, Veeraraghavan B. Characterization of Pseudomonas aeruginosa with discrepant carbapenem susceptibility profile. Ann Clin Microbiol Antimicrob. 2016;15:12.

113. Buehrle DJ, Shields RK, Chen L, et al. Evaluation of the in vitro activity of ceftazidime-avibactam and ceftolozane-tazobactam against meropenem-resistant Pseudomonas aeruginosa isolates. Antimicrob Agents Chemother. 2016;60(5):3227-3231.

114. Kos VN, McLaughlin RE, Gardner HA. Identification of unique in-frame deletions in OprD among clinical isolates of Pseudomonas aeruginosa. Pathog Dis. 2016;74(4):ftw031.

115. Kao CY, Chen SS, Hung KH, et al. Overproduction of active efflux pump and variations of OprD dominate in imipenem-resistant Pseudomonas aeruginosa isolated from patients with bloodstream infections in Taiwan. BMC Microbiol. 2016;16(1):107.

116. Iyer R, Sylvester MA, Velez-Vega C, Tommasi R, Durand-Reville TF, Miller AA. Whole-cell-based assay to evaluate structure permeation relationships for carbapenem passage through the Pseudomonas aeruginosa porin OprD. ACS Infect Dis. 2017;3(4):310-319.

117. Shu JC, Kuo AJ, Su LH, et al. Development of carbapenem resistance in Pseudomonas aeruginosa is associated with OprD polymorphisms, particularly the amino acid substitution at codon 170. J Antimicrob Chemother. 2017;72(9):2489-2495.

118. Richardot C, Plesiat P, Fournier D, Monlezun L, Broutin I, Llanes C. Carbapenem resistance in cystic fibrosis strains of Pseudomonas aeruginosa as a result of amino acid substitutions in porin OprD. Int $J$ Antimicrob Agents. 2015;45(5):529-532.

119. Choudhury D, Talukdar AD, Choudhury MD, et al. Carbapenem nonsusceptibility with modified OprD in clinical isolates of Pseudomonas aeruginosa from India. Indian J Med Microbiol. 2017;35(1):137-139.

120. Naenna P, Noisumdaeng P, Pongpech P, Tribuddharat C. Detection of outer membrane porin protein, an imipenem influx channel, in Pseudomonas aeruginosa clinical isolates. Southeast Asian JTrop Med Public Health. 2010;41(3):614-624.

121. Mussi MA, Relling VM, Limansky AS, Viale AM. CarO, an Acinetobacter baumannii outer membrane protein involved in carbapenem resistance, is essential for L-ornithine uptake. FEBS Lett. 2007;581(29):5573-5578.

122. Schulz GE. The structure of bacterial outer membrane proteins. Biochim Biophys Acta. 2002;1565(2):308-317.

123. Ghai I, Bajaj H, Bafna JA, Damrany Hussein HAE, Winterhalter M, Wagner R. Ampicillin permeation across OmpF, the major outer membrane channel in E. coli. J Biol Chem. Epub 2018 Mar 14. 


\section{Publish your work in this journal}

Infection and Drug Resistance is an international, peer-reviewed openaccess journal that focuses on the optimal treatment of infection (bacterial, fungal and viral) and the development and institution of preventive strategies to minimize the development and spread of resistance. The journal is specifically concerned with the epidemiology of antibiotic resistance and the mechanisms of resistance development and diffusion in both hospitals and the community. The manuscript management system is completely online and includes a very quick and fair peerreview system, which is all easy to use. Visit http://www.dovepress.com/ testimonials.php to read real quotes from published authors.

Submit your manuscript here: https://www.dovepress.com/infection-and-drug-resistance-journal 